\title{
PENGARUH PENDIDIKAN KESEHATAN TERHADAP TINGKAT PENGETAHUAN TENTANG PEMERIKSAAN PAYUDARA SENDIRI (SADARI)
}

\author{
Rizqy Iftitah Alam', Subhan ${ }^{2}$ \\ rizqyiftitah.alam@umi.ac.id \\ 1,2 Program Studi Ilmu Keperawatan, Fakultas Kesehatan Masyarakat \\ Universitas Muslim Indonesia
}

\begin{abstract}
ABSTRAK
Pendahuluan. Kanker payudara merupakan masalah kesehatan dan penyebab kematian pada wanita di seluruh dunia. Minimnya pengetahuan masyarakat tentang kanker payudara membuat pencegahan dan penanganan dini pun sulit dilakukan. Salah satu pencegahan kanker payudara yakni dengan melakukan pemeriksaan payudara sendiri. Pemeriksaan payudara sendiri (SADARI) merupakan salah satu cara yang efisien dan efektif sebagai pendeteksi dini kanker payudara selain momografi. Metode. Penelitian ini menggunakan metode Pre Experimental dengan one group pre-test post-test design. Instrument yang digunakan dalam penelitian ini adalah kuesioner yang berisi pertanyaan mengenai pengetahuan responden tentang SADARI. Hasil. Ada pengaruh pemberian pendidikan kesehatan tentang Pemeriksaan Payudara Sendiri (SADARI) terhadap tingkat pengetahuan siswi kelas XI Jurusan IPA SMA Negeri 9 Gowa dengan nilai $p$ value 0,185 serta nilai signifikan 0,327 yang lebih besar dari nilai $\alpha$ 0,05.Diskusi. Diharapkan hasil penelitian ini nantinya dapat memberikan manfaat kepada banyak orang, khususnya kepada seluruh perempuan baik remaja maupun dewasa untuk dapat melakukan deteksi dini adanya tanda-tanda kanker payudara sehingga pengobatan dapat diberikan sesegera mungkin. Penelitian ini juga diharapkan dapat menjadi bahan informasi bagi khalayak umum.
\end{abstract}

Kata Kunci : Pendidikan kesehatan, pengetahuan, SADARI

\section{ABSTRACT}

Preliminary. Breast cancer is a health problem and causes of death in women throughout the world. Lack of public knowledge about cancer makes it difficult and early treatment difficult. One checks for breast cancer by checking the breasts themselves. Breast self-examination (BSE) is one of the efficient and effective ways for early detection of breast cancer in addition to momography. Method This study uses a Pre-Experimental method with the design of one group pre-test post-test. The instrument used in this study was a questionnaire containing questions about respondents' knowledge about BSE. Results. There is a contribution of health education on Breast SelfExamination (BSE) to the level of knowledge of class XI students of the Department of Natural Sciences 9 Gowa High School with a p value of 0.185 and a significant value of 0.327 which is greater than the value of $\alpha 0.05$. Discussion. It is expected that the results of this study can provide benefits for many people, especially for women both adolescents and adults to be able to detect early signs of breast cancer so that it can be given as soon as possible. This research is also expected to be material information for the general public.

Keywords: Health education, knowledge, BSE 


\section{PENDAHULUAN}

Saat ini perkembangan penduduk terjadi di seluruh dunia, terutama perkembangan dalam bidang kesehatan. Tetapi masalah kesehatan merupakan ancaman bagi negaranegara yang sedang berkembang sehingga masalah kesehatan menjdai tidak terkontrol. Salah satu penyakit yang mengalami peningkatan adalah kanker. Stigma masyarakat yang percaya tentang mitos kanker yang salah satunya bahwa tidak ada yang dapat dilakukan terkait dengan kanker. Penyakit kanker sendiri sebenarnya dapat dicegah, diobati, dan disembuhkan jika diketahui lebih dini tanda dan gejala kanker (Depkes RI, 2014).

Kanker payudara yang juga disebut ca mamae merupakan pertumbuhan sel payudara yang tidak terkontrol karena terjadi perubahan abnormal dari gen yang berperan dalam pembelahan sel. Kanker payudara sampai saat ini masih menjadi masalah karena merupakan jenis kanker yang angka kejadiannya paling tinggi di Indonesia. Kejadian kanker payudara meningkat sesuai dengan bertambahnya usia. Akan tetapi, usia muda juga bukan jaminan aman dari kanker payudara (Yayasan Kanker Indonesia, 2008).

Salah satu pencegahan kanker payudara yakni dengan melakukan pemeriksaan payudara sendiri. Pemeriksaan payudara sendiri (SADARI) merupakan salah satu cara yang efisien dan efektif sebagai pendeteksi dini kanker payudara selain momografi. Kegagalan penemuan secara dini kanker payudara dapat terjadi dikarenakan kurangnya pengetahuan atau informasi yang diperoleh masyarakat. Banyak penderita kanker payudara datang ke rumah sakit dengan kondisi stadium lanjut dikarenakan penderita tidak merasa adanya perubahan dengan kondisi pada payudaranya (Oemiati, Rahajeng, dan Kristanto, 2011).

Alasan lain mengapa perempuan tidak melakukan atau kurangnya motivasi untuk melakukan pemeriksaan payudara sendiri dikarenakan mereka merasa takut apabila setelah melakukan pemeriksaan payudara sendiri, perempuan menemukan suatu benjolan yang tidak normal pada payudaranya. Hal tersebut sebenarnya dapat membantu seorang perempuan mendapatkan terapi secepat mungkin sebelum kanker menjadi stadium lanjut (Soemitro, 2012).

Berdasarkan hasil observasi dan wawancara awal yang dilakukan di SMA Negeri 9 Gowa, ditemukan sebagian besar siswi di sekolah tersebut yang masih awam dengan yang namanya Pemeriksaan Payudara Sendiri (SADARI). Bahkan masih banyak siswi tersebut yang bahkan tidak mengetahui sama sekali tentang Pemeriksaan Payudara Sendiri (SADARI). Kebanyakan mereka tidak mengetahui bagaimana cara melakukan pemeriksaan payudara sendiri untuk bisa mendeteksi tentang resiko awal terjadinya kanker payudara.

Dari latar belakang yang telah diuraikan di atas, peneliti kemudian tertarik untuk meneliti apakah ada pengaruh pemberian pendidikan kesehatan terhadap tingkat pengetahuan tentang pemeriksaan payudara sendiri (SADARI) pada siswi kelas XI jurusan IPA SMA Negeri 9 Gowa.

\section{METODE}

Desain Penelitian

McMcillan dalam Lapau (2013)

menyatakan bahwa desain penelitian 
adalah rencana dan struktur yang digunakan untuk memperoleh buktibukti empiris atau fakta dalam menjawab pertanyaan penelitian. Penelitian ini menggunakan metode Pre Experimental dengan one group pre-test post-test design.

\section{Lokasi}

Penelitian ini dilaksanakan di SMA Negeri 9 Gowa.

\section{Populasi dan Sampel}

Populasi merupakan subjek atau objek yang mempunyai kualitas dan karakteristik tertentu yang telah ditetapkan oleh peneliti untuk dipelajari dan kemudian ditarik kesimpulannya (Sugiyono, 2011). Populasi dalam penelitian ini adalah seluruh siswi kelas XI jurusan IPA SMA Negeri 9 Gowa yang berjumlah kurang lebih 80 orang.

Sementara sampel dalam penelitian ini sebanyak 20 orang. Namun, untuk mengantisipasi adanya kemungkinan hilangnya data atau ketidaklengkapan kuesioner, maka akan ditambah 10 orang dari jumlah sampel di atas, sehingga sampel yang digunakan dalam penelitian ini sebanyak 30 responden.

\section{Instrumen Penelitian}

Instrument yang digunakan dalam penelitian ini adalah kuesioner. Peneliti menggunakan kuesioner yang sudah dilakukan uji valid oleh Dena (2015), kuesioner yang berisi pertanyaan mengenai pengetahuan responden tentang SADARI.

\section{Analisis Data}

\section{Analisis Univariat}

\begin{abstract}
Analisis ini digunakan untuk menjelaskan atau mendeskripsikan karakteristik dari masing-masing variabel yang diteliti.
\end{abstract}

\section{Analisis Bivariat}

Dalam penelitian ini analisis data yang digunakan yaitu dengan uji paired sample $T$ testkarena penelitian ini menggunakan skala interval dan akan menghasilkan dua data, yaitu pre-test dan posttest dari satu kelompok variabel yang sama yaitu pengetahuan.Untuk mengetahui apakah ada pengaruh antara variabel independen (pendidikan kesehatan) terhadap variabel dependen (pengetahuan), maka $p$ value dibandingkan dengan tingkat kesalahan yang digunakan $(\alpha=0,05)$. Apabila $p$ value $<\alpha$, maka Ho ditolak yang berarti ada pengaruh antara variabel independen terhadap variabel dependen.

\section{HASIL}

\section{Analisis Univariat Tabel 1 Gambaran Distribusi Responden Berdasarkan Tingkat Pengetahuan Siswi Kelas XI Jurusan IPA SMA Negeri 9 Gowa Sebelum diberikan Intervensi}

\begin{tabular}{|c|c|c|}
\hline Kriteria & Frekuensi & $\begin{array}{c}\text { Valid } \\
\text { Percent }\end{array}$ \\
\hline $\begin{array}{c}\text { Pengetahuan } \\
\text { Baik }\end{array}$ & 14 & 46.7 \\
\hline $\begin{array}{l}\text { Pengetahuan } \\
\text { Kurang }\end{array}$ & 16 & 53.3 \\
\hline Total & 30 & 100.0 \\
\hline
\end{tabular}

Berdasarkan Tabel 1. di atas, diperoleh hasil bahwa jumlah siswi yang memiliki pengetahuan 
baik sebanyak 14 orang (46.7\%), sedangkan jumlah siswi yang memiliki pengetahuan kurang sebanyak 16 orang $(53.3 \%)$.

Tabel 2Gambaran Distribusi

Responden Berdasarkan

Tingkat Pengetahuan Siswi

Kelas XI Jurusan IPA SMA

Negeri 9 Gowa Sesudah diberikan Intervensi

\begin{tabular}{ccc}
\hline Kriteria & Frekuensi & $\begin{array}{c}\text { Valid } \\
\text { Percent }\end{array}$ \\
\hline $\begin{array}{c}\text { Pengetahuan } \\
\text { Baik }\end{array}$ & 30 & 100.0 \\
$\begin{array}{c}\text { Pengetahuan } \\
\text { Kurang } \\
\text { Total }\end{array}$ & 0 & 0.0 \\
\hline
\end{tabular}

Berdasarkan Tabel 4.2a di atas, diperoleh hasil bahwa setelah diberikan intervensi seluruh siswi memiliki tingkat pengetahuan baik yakni sebanyak 30 orang dengan persentase $100 \%$.

Analisis Bivariat

Tabel 3 Paired Sample

TestDistribusi Responden

Berdasarkan Tingkat

Pengetahuan

(Sebelum/Sesudah) Siswi Kelas

XI Jurusan IPA SMA Negeri 9

Gowa

\begin{tabular}{cccccc}
\hline & Mean & $\begin{array}{c}\text { Std. } \\
\text { Deviation }\end{array}$ & T & Df & $\begin{array}{c}\text { Sig. } \\
(\mathbf{2}- \\
\text { talled) }\end{array}$ \\
\hline $\begin{array}{c}\text { Pair 1 } \\
\text { Sebelum } \\
\text { dan }\end{array}$ & - & 1.732 & - & 29 & .000 \\
Sesudah & & & 10.648 & & \\
\hline
\end{tabular}

Berdasarkan hasil uji statistik pada tabel 4.2 di atas, diperoleh nilai Mean -3.367 dengan nilai signifikan (2-talled) < dari nilai 0,05 yang berarti terdapat perubahan pengetahuan yang signifikan setelah diberikan pendidikan kesehatan tentang Pemeriksaan Payudara Sendiri (SADARI) pada siswi kelas XI Jurusan IPA SMA Negeri 9 Gowa.

\section{PEMBAHASAN}

Berdasarkan hasil penelitian tersebut di atas, diperoleh hasil bahwa terdapat perubahan yang signifikan terhadap tingkat pengetahuan siswi kelas XI Jurusan IPA SMA Negeri 9 Gowa setelah diberikan pendidikan kesehatan berupa penyuluhan tentang Pemeriksaan Payudara Sendiri (SADARI).

Pengetahuan merupakan hasil dari tahu, dan ini terjadi setelah orang melakukan pengindraan terhadap suatu objek tertentu. Pengindraan terjadi melalui panca indra manusia, yakni indra pengelihatan, pendengaran, penciuman, rasa, dan raba. Sebagian besar pengetahuan manusia diperoleh melalui mata dan telinga (Notoatmodjo, 2007).

Menurut Notoatmodjo (2010) mengemukakan bahwa pengetahuan terjadi setelah orang melakukan pengindraan terhadap objek tertentu. Pengindraan yang baik akan meningkatkan pemahaman terhadap suatu objek atau informasi. Oleh karena itu meski responden pernah mendapat informasi mengenai kanker payudara tanpa pengindraan dengan baik maka pemahaman responden kurang baik.

Pengetahuan dapat bertambah atau meningkat dengan adanya informasi dengan menggunakan berbagai macam media yaitu ada

media cetak dan media elektronik. Adapun media cetak itu antara lain : poster, leaflet, brosur, majalah, surat 
kabar, stiker dan pamflet, sedangkan media elektronik misalnya : televisi, radio dan tape recorder, vcd, video.

Hal ini sebanding dengan penelitian yang dilakukan oleh Viviyawati (2013) di SMKN 1 Karanganyar yang menunjukkan bahwa ada pengaruh pendidikan kesehatan dengan video tentang pemeriksaan payudara sendiri (SADARI) terhadap pengetahuan remaja putri. Penelitian yang di lakukan oleh Nugrahini (2012) tentang hubungan tingkat pengetahuan dengan perilaku sadari pada mahasiswa Fakultas Ilmu Keperawatan Universitas Padjajaran Bandung Jawa Barat. Hasil penelitiannya menunjukkan bahwa mayoritas mahasiswa $(56,25 \%)$ memiliki perilaku yang sesuai dalam melakukan SADARI, dan sebanyak $(43,75 \%)$ memiliki perilaku yang tidak sesuai dalam melakukan SADARI. Dari hasil penelitian yang sudah dilakukan pada mahasiswa yang tidak sesuai dalam melakukan SADARI adalah disebabkan karena mahasiswa tidak mengetahui langkahlangkah dan teknik SADARI, frekuensi dan waktu pelaksanaan SADARI.

\begin{tabular}{lrr}
\multicolumn{1}{c}{ Dengan } & \multicolumn{2}{c}{ diberikannya } \\
penyuluhan & kesehatan & tentang \\
Pemeriksaan & Payudara & Sendiri
\end{tabular}

(SADARI), siswi-siswi tersebut dapat mengetahui manfaat dari Pemeriksaan Payudara Sendiri (SADARI) serta dapat menimbulkan kesadaran dan kemauan untuk lebih memerhatikan dan menjaga kesehatannya lebih baik lagi. Selain itu, dengan diberikannya penyuluhan kesehatan tentang SADARI, diharapkan dapat mendeteksi dini terjadinya kanker payudara sehingga pengobatan dapat diberikan sesegera mungkin.

\section{KESIMPULAN DAN SARAN Kesimpulan}

Ada pengaruh pemberian pendidikan kesehatan tentang Pemeriksaan Payudara Sendiri (SADARI) terhadap tingkat pengetahuan siswi kelas XI Jurusan IPA SMA Negeri 9 Gowa dengan nilai $p$ value 0,185 serta nilai signifikan 0,327 yang lebih besar dari nilai $\alpha 0,05$.

\section{Saran}

Diharapkan hasil penelitian ini nantinya dapat memberikan manfaat kepada banyak orang, khususnya kepada seluruh perempuan baik remaja maupun dewasa untuk dapat melakukan deteksi dini adanya tanda-tanda kanker payudara sehingga pengobatan dapat diberikan sesegera mungkin. Penelitian ini juga diharapkan dapat menjadi bahan informasi bagi khalayak umum.

\section{DAFTAR PUSTAKA}

Depkes RI. 2014. Hilangkan Mitos Tentang Kanker. http://www.depkes.go.id diakses 5 Mei 2015 pukul 20.00 WIB

Indriani. Tiara. 2017. Efektifitas Penyuluhan Kesehatan SADARI dengan Media Video Terhadap Pengetahuan pada Remaja Putri di SMK YMJ Ciputat. Skripsi.

Kartikawati, Erni, Awas!!! Bahaya Kanker Payudara \& Kanker Serviks (Edisi Pertama). Bandung: Buku Baru

Kholid, Ahmad. 2012. Promosi Kesehatan: Dengan Pendekatan Teori Perilaku, Media, Dan Aplikasinya. Jakarta: Rajawali Pers

Manuaba, Tjakra W. 2010. Panduan Penatalaksanaan Kanker Solid Peraboi 2010. Jakarta: Sagung Seto 
Notoatmodjo, S. 2010. Ilmu Perilaku Kesehatan. Jakarta: Rineka Cipta

Oemiati, R, Rahajeng, E, dan Kristanto, A. Y. 2011. Prevalensi Tumor Dan Beberapa Faktor Yang Mempengaruhinya Di Indonesia. Bulletin of Health Research. Vol. 39, No.4, 2011: 190 - 204.

Siregar,R. 2012. Kenali dan pahami gejala kanker payudara. Terdapat pada: http://perpustakaan.untirta.

ac.id/berita-151-kenali-dan-pahamigejala-kanker-

payudara.html.Diakses pada tanggal 28 Maret 2016

Suastina, I.D.A.R, Ticoalu S.H.R dan Onibala, F. 2013. Pengaruh Pendidikan Kesehatan Terhadap Tingkat Pengetahuan Siswi Tentang Sadari Sebagai Deteksi Dini Kanker Payudara Di Sma Negeri 1 Manado. Jurnal Keperawatan. Volume 1. Nomor 1. Agustus 2013.

Viviyawati, T. 2014. Pengaruh Pendidikan Kesehatan tentang Pemeriksaan SADARI sebagai Deteksi Dini Kanker Payudara Terhadap Pengetahuan dan Sikap Remaja di SMK Negeri 1 Karanganyar. Surakarta : STIKES Kusuma Husada. 